\title{
Serological Studies on Nephrotic Syndrome of Quartan Malaria in Uganda
}

\author{
J. W. KIBUKAMUSOKE, ${ }^{*}$ M.D., F.R.C.P.ED. ; A. VOLLER,† PH.D.
}

ummary : Ugandans with high malarial antibody titres $\checkmark$ have been found also to have higher IgM levels. Patients with active nephrotic syndrome have higher IgM and malarial antibody levels than both controls and nephrotics in remission, an extreme increase in these factors being found in patients in whom immune complexes were present.

\section{Introduction}

Hendrickse and Gilles (1963) reported on the association between the nephrotic syndrome and quartan malaria in West African children. Evidence has since accumulated which suggests that circulating antigen-antibody complexes are involved in the renal damage (Soothill and Hendrickse, 1967; Allison et al., 1969; Ward and Kibukamusoke, 1969). We thought that this apparently abnormal immunological response to malarial infection might be reflected in the serum immunoglobulin and malarial antibody levels, and the present study represents an attempt to assess the immunoglobulins $\operatorname{IgM}$ and IgG and the malarial antibody levels in a group of nephrotics in Uganda.

\section{Materials and Methods}

The study group consisted of 53 Ugandans with the nephrotic syndrome ( 34 active and 19 in remission) and a comparable group of 19 non-nephrotic controls. Malarial antibody was measured by the indirect fluorescent antibody method described by Voller (1964). The antigen used was thin blood smears of Plasmodium falciparum made from experimentally infected Aotus trivirgatus (owl monkeys). The values given are the reciprocal of the terminal serum dilutions yielding detectable fluorescence.

The estimations of immunoglobulins IgG and IgM were carried out by the radial diffusion method with specific antibody in agar-gel plates (Mancini et al., 1963) purchased from Hyland Laboratories, California, U.S.A. Sera were diluted for re-testing when the diameter of the precipitation zones were greater than that of the highest standard immunoglobulin preparations available. (IgG and IgM values are expressed as mg./100 ml. serum).

The Student $t$ test was used for the statistical analysis of the results.

\section{Results}

The individual and mean values for $\operatorname{IgG}, \operatorname{IgM}$, and malarial antibody titres in active nephrotics, nephrotics in remission, and the control Ugandans are given in Table I. The IgG

\footnotetext{
* Professor of Clinical Medicine, Mulago Hospital, Makerere University College, Kampala, Uganda.

t Senior Lecturer, Department of Clinical Tropical Medicine, London School of Hygiene and Tropical Medicine, London W.C.1.
}

TABLE I.-Immunoglobulin and Malarial Antibody Levels

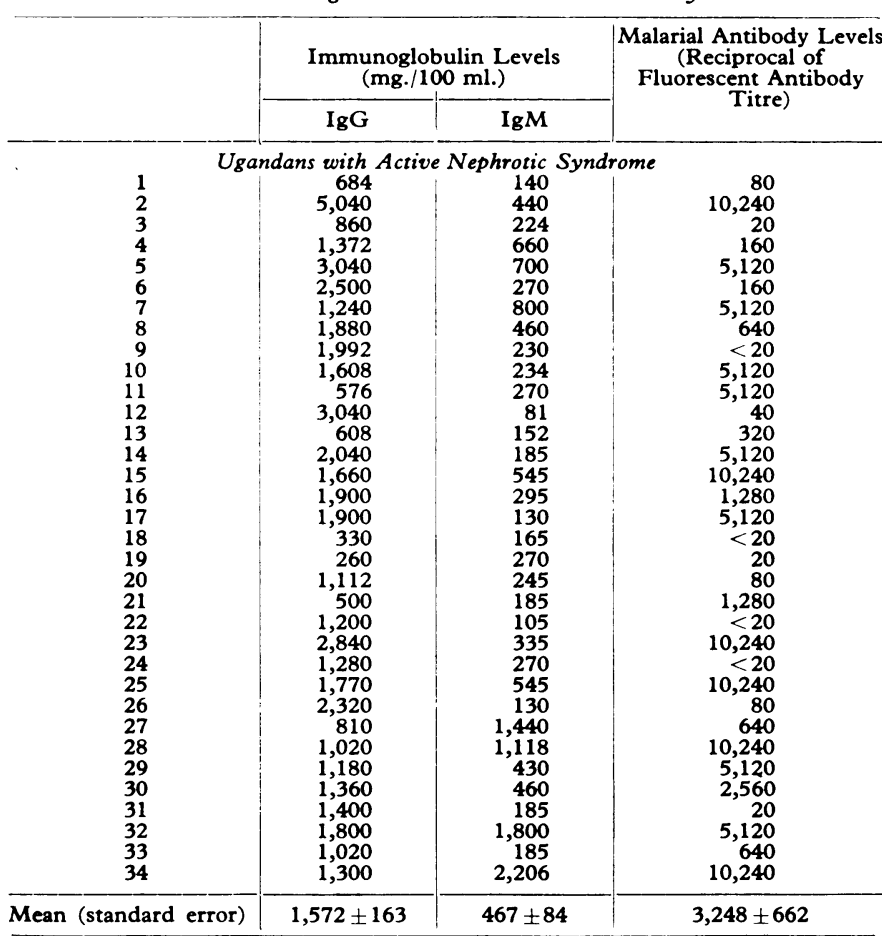

\begin{tabular}{|c|c|c|c|}
\hline \multicolumn{4}{|c|}{ Ugandans whose nephrotic syndrome was in state of remission } \\
\hline $\begin{array}{r}1 \\
2 \\
3 \\
4 \\
5 \\
6 \\
7 \\
8 \\
9 \\
10 \\
11 \\
12 \\
13 \\
14 \\
15 \\
16 \\
17 \\
18 \\
19\end{array}$ & $\begin{array}{r}3,200 \\
1,880 \\
2,500 \\
1,700 \\
860 \\
1,880 \\
760 \\
1,608 \\
3,040 \\
3,040 \\
1,992 \\
440 \\
1,000 \\
1,180 \\
1,992 \\
1,560 \\
2,040 \\
1,800 \\
1,372\end{array}$ & $\begin{array}{r}220 \\
107 \\
1,000 \\
198 \\
66 \\
160 \\
276 \\
236 \\
236 \\
246 \\
205 \\
147 \\
185 \\
92 \\
245 \\
117 \\
165 \\
205 \\
105\end{array}$ & $\begin{array}{r}5,120 \\
80 \\
5,120 \\
10,240 \\
20 \\
2,560 \\
20 \\
5,120 \\
20 \\
5,120 \\
10,240 \\
<20 \\
4,120 \\
80 \\
5,120 \\
<20 \\
80 \\
80 \\
40\end{array}$ \\
\hline Mean (standard error) & $1,781 \pm 178$ & $221 \pm 45$ & $2,852 \pm 801$ \\
\hline \multicolumn{4}{|c|}{ Ugandans without nephrotic syndrome } \\
\hline $\begin{array}{r}1 \\
2 \\
3 \\
4 \\
5 \\
6 \\
7 \\
8 \\
9 \\
10 \\
11 \\
12 \\
13 \\
14 \\
15 \\
16 \\
17 \\
18 \\
19\end{array}$ & $\begin{array}{c}3,200 \\
2,600 \\
1,500 \\
2,600 \\
2,200 \\
1,800 \\
1,520 \\
2,500 \\
2,320 \\
2,200 \\
1,800 \\
\text { Not done } \\
1,992 \\
2,880 \\
1,880 \\
2,600 \\
2,100 \\
3,040 \\
4,400\end{array}$ & $\begin{array}{r}246 \\
360 \\
220 \\
220 \\
236 \\
238 \\
98 \\
220 \\
236 \\
224 \\
128 \\
224 \\
220 \\
238 \\
220 \\
260 \\
242 \\
254 \\
300\end{array}$ & $\begin{array}{r}20 \\
640 \\
80 \\
80 \\
<20 \\
<20 \\
80 \\
160 \\
40 \\
1,280 \\
80 \\
640 \\
160 \\
2,560 \\
<20 \\
160 \\
40 \\
160 \\
640\end{array}$ \\
\hline Mean (standard error) & $2,392 \pm 165$ & $230 \pm 12$ & $360 \pm 144$ \\
\hline
\end{tabular}


values of the three groups are not significantly different. The group with active nephrotic syndrome have significantly higher IgM levels than the controls and the nephrotics in remission $(0.05>P>0.025)$. Malarial fluorescent antibody levels are higher in the active nephrotics than in the control group (0.01 $>\mathrm{P}>0.005)$. The nephrotics in remission also have higher mean malarial antibody levels than the controls, but the difference is not statistically significant $(0 \cdot 10>P>0.05)$.

In Table II the immunoglobulin levels are analysed with

TABLE II.-Immunoglobulin Levels of Ugandans Analysed in Relation to Their Malarial Antibody Titres

\begin{tabular}{|c|c|c|c|c|c|c|}
\hline & \multicolumn{3}{|c|}{$\begin{array}{l}\text { Low Malarial Antibody } \\
\text { Levels } \\
\text { (F.A. Titre } 320 \text { or less) }\end{array}$} & \multicolumn{3}{|c|}{$\begin{array}{l}\text { High Malarial Antibody } \\
\text { Levels } \\
\text { (F.A. Titre above 320) }\end{array}$} \\
\hline & No. & $\begin{array}{c}\mathrm{IgM} \\
\text { (mg./1 } \\
\text { Mean (Star }\end{array}$ & \begin{tabular}{|c|}
$\mathrm{IgG}$ \\
$00 \mathrm{ml.})$ \\
dard Error)
\end{tabular} & No. & $\begin{array}{c}\text { IgM } \\
\text { (mg./10 } \\
\text { Mean (Stan }\end{array}$ & $\begin{array}{c}\text { IgG } \\
00 \mathrm{ml} .) \\
\text { dard Error) }\end{array}$ \\
\hline $\begin{array}{l}\text { Active nephrotics } \\
\text { Nephrotics in }\end{array}$ & 14 & $223+38$ & $1,354 \pm 223$ & 20 & $638 \pm 128$ & 1,76 \\
\hline $\begin{array}{lll} & & \\
\text { Comission } \\
\text { Controls } & \ldots & \ldots\end{array}$ & $\begin{array}{l}10 \\
14\end{array}$ & $\begin{array}{l}151 \div 22 \\
217 \pm 12\end{array}$ & $\begin{array}{l}1,486 \pm 266 \\
2,212 \pm 141\end{array}$ & $\begin{array}{l}9 \\
5\end{array}$ & $\begin{array}{l}299 \pm 88 \\
269 \pm 27\end{array}$ & $\begin{array}{l}2,101+234 \\
3,020+480 \\
\text { (based on } 4 \\
\text { values only) }\end{array}$ \\
\hline All groups combined & 38 & $202 \div 16$ & $1,709+129$ & 34 & $494+83$ & $1,984 \div 174$ \\
\hline
\end{tabular}

respect to malarial antibody levels. The data are analysed in this way because a high titre of malarial antibody indicates that an individual has experienced malaria recently. The IgG values are similar in the high and low malarial antibody groups. The mean $\operatorname{IgM}$ value, however, is much greater in the high malarial antibody group $(0.005>P>0.0025)$. The active nephrotics with high malarial antibody values have even higher IgM concentrations in their sera than both the remitted nephrotics and controls with high malarial antibody titres $(0.05>\mathrm{P}>0.025)$.

The data of Ward and Kibukamusoke (1969) on the presence or absence of immune-complex deposition in renal biopsies is utilized for further analysis of our results on serum immunoglobulin levels and malarial antibody levels. Twentytwo of their nephrotic patients are included in the present study and the results are given in Table III. The IgM is sig-

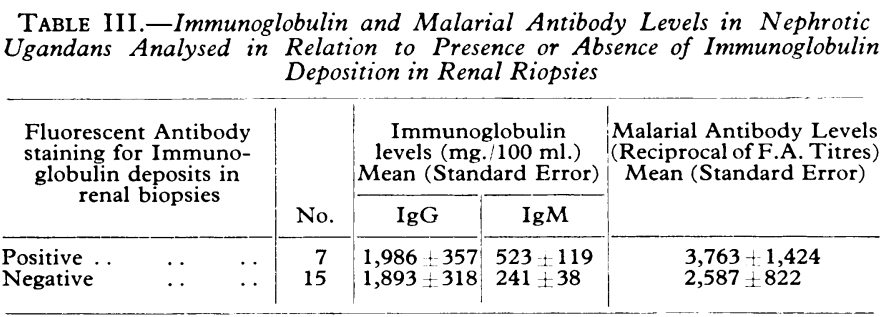

nificantly higher $(0.01>P>0.005)$ in the group with renal immune-complex deposits than in the group without such deposits. IgG and malarial antibody levels were similar in both groups.

\section{Discussion}

The present work shows that there is a strong correlation between the rise in IgM and high malarial antibody levels in both control and nephrotic groups of Ugandans. This suggests a common aetiological agent which is, in all probability, malaria. Unfortunately the serological techniques used here for the estimation of antibodies do not permit reliable identification of the species of malaria parasite which stimulated the antibody production.

The group of patients with the nephrotic syndrome had higher IgM and malarial antibody levels than the controls, but the IgG values were similar in both groups. Since $P l$. malariae has been shown to be the causative agent of the African nephrotic syndrome (Hendrickse and Gilles, 1963; Kibukamusoke et al., 1967) it is probably responsible for the higher serum concentrations of IgM and malarial antibody in the nephrotics. A possible explanation is that the malarial antibody is in the IgM fraction of the serum. This has, however, been excluded, as immunofluorescent tests for malarial antibody with monospecific labelled antisera to $\operatorname{IgM}$ and IgG show that most of the malarial antibody detected by the standard fluorescent antibody procedure is in the IgG class (Voller, unpublished).

Recent work (Allison et al., 1969; Ward and Kibukamusoke, 1969) has shown that the nephrotics often have glomerular deposits of $\operatorname{IgM}, \operatorname{IgG}, \operatorname{Ig} A$, and complement, with $\operatorname{IgM}$ predominating. In this context it is particularly interesting that the high antibody group of active nephrotics should have significantly greater serum IgM concentrations than the high-antibody representatives in the controls and nephrotics in remission. Similarly the nephrotics with immune-complex glomerular deposits have higher IgM levels than nephrotics without the demonstrable immune complexes.

The nephrotic patients may represent individuals who produce an excessive amount of $\operatorname{IgM}$ in response to malarial infection, though it is conceivable that there is an abnormal host response that affects $\operatorname{IgM}$ and malarial antibodies independently.

Newer techniques for the precise identification of soluble malarial antigens and antibodies (Wilson et al., 1969) may lead to greater resolution of the mechanism by which the nephrotic syndrome develops.

Financial assistance for this work was generously provided by the World Health Organization and the Medical Research Council.

The skilled technical assistance of Mrs. D. G. Green is gratefully acknowledged.

\section{REFERENCES}

Allison, A. C., et al., (1969). Lancet, 1, 1232.
Hendrickse, R. G., and Gilles, H. M. (1963). East African Medical fournal, 40, 186.

Kibukamusoke, J. W., Hutt, M. S. R., and Wilks, N. E. (1967). Quar-

terly Fournal of Medicine, 36, 393.
Mancini, G., Vaerman, J. P., Carbonara, A. O., and Heremans, J. F. (1963). In Proceedings of the 11th Colloquium on Protides of the Biological Fluids. Edited by H. Peeters, p. 370 . Amsterdam, Elsevier. Soothill, J. F., and Hendrickse, R. G. (1967). Lancet, 2, 629.

Voller, A. (1964). Bulletin of the World Health Organization, 30, 343 Ward, P. A., and Kibukamusoke, J. W. (1969). Lancet, 1, 283.

Wilson, R. J. M., McGregor, I. A., Hall, P., Williams, K., and Bartholomew, R. (1969) Lancet, 2, 201. 